的究短報交

\title{
橄欖石熔體の粘度に就きて
}

理學士·可兒弘一

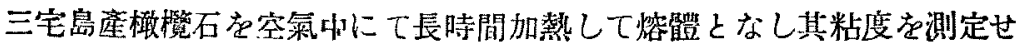
るを以て其結果の概要を報告せん。本橄攬石の化學成分並に光學的性質に 就ては神津郄授の記述せられたるものあり(第一表)。

\begin{tabular}{|c|c|}
\hline \multicolumn{2}{|c|}{ 化學分析表 } \\
\hline $\mathrm{S}_{2} \mathrm{O}_{2}$ & 35.82 \\
\hline $\mathrm{Al}_{2} \mathrm{O}_{3}$ & 0.20 \\
\hline $\mathrm{FC}_{2} \mathrm{O}_{3}$ & 1.65 \\
\hline H.O & 14.93 \\
\hline $\mathrm{MgO}$ & 42.51 \\
\hline $\mathrm{CaO}$ & 0.40 \\
\hline $\mathrm{ZiO}_{2}$ & none \\
\hline$M n O$ & 0.23 \\
\hline$L . I$. & 0.90 \\
\hline Total & 99.64 \\
\hline
\end{tabular}

\begin{tabular}{|c|}
\hline 光學的性貿 \\
\hline$\alpha=1.668$ \\
$\beta=1.687$ \\
$\gamma=1.706$ \\
\hline
\end{tabular}

第一表の化學分析の結果より算出せる成分式は分 子百分比 $17.2 \mathrm{Fe}_{2} \mathrm{SiO}_{4} \cdot 82.8: \mathrm{Mg}_{2} \mathrm{SiO}_{4}$, 重量百分比 にて23.I $\mathrm{Fe}_{2} \mathrm{SiO}_{4} \cdot 76.9 \mathrm{Mg}_{2} \mathrm{SiO}_{4}$ なり（但し $\mathrm{Fe}_{2}$ $\mathrm{O}_{3}$ は $\mathrm{FeO}$ として舞算せり。)

\section{䗙 驗}

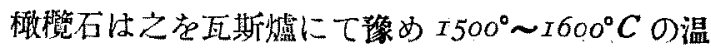
度に加畀し本融狀態に成せるものを實驗試料として 使用せり。粘度の测定に際して，試料を白金圓筒中 に入れ，順次温度を上昇し $I 500^{\circ} \mathrm{C}$ に至るも熔融の 北䟞なき学以更に温度を $1550^{\circ} \mathrm{C}$ に上昇し,長時間 放置せるに娜く燃體となれるを認めたり。而して趈 轔體党雨入して $1560^{\circ} \mathrm{C}$ より粘度の测定を開始せり。 粘度の测定結果怔第二表及び第三表に示せり。第二表は荷重々一分間の廻 轉數との關係, 第三表は $\mathrm{k}$ 及び $\mathrm{k}$ の值及び粘度值なり。粘度の测定方法は

1) 神津做游，地球，第九管四躆(昭和三年四月) 

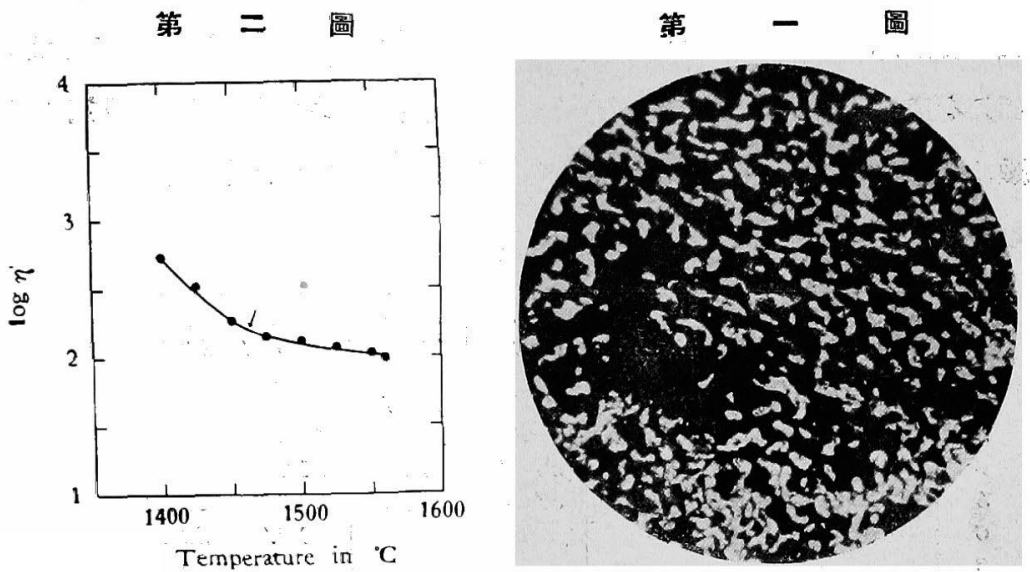

$\times 60$

橵㰖石結晶し１00面に平行なる断面

$1550^{\circ} \mathrm{C}$ に 30 分間加熹せるるの 濃色……分解せる部分

淡色……分解せざる部分

第三圖

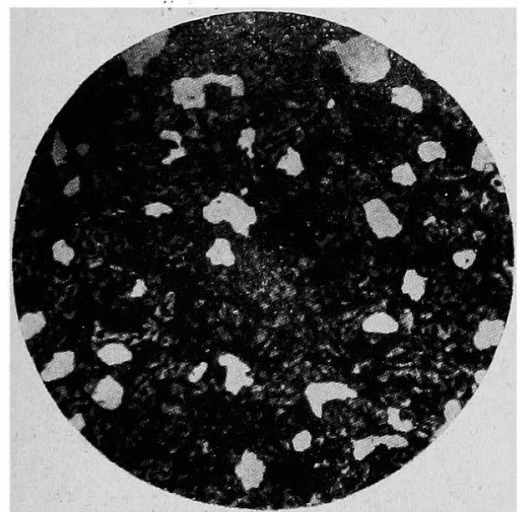

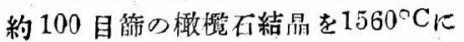
30 分如熹せるもの
湛色……分解せる部分
淡色……分解せざる部分
白色……㳟間

第 四 圖

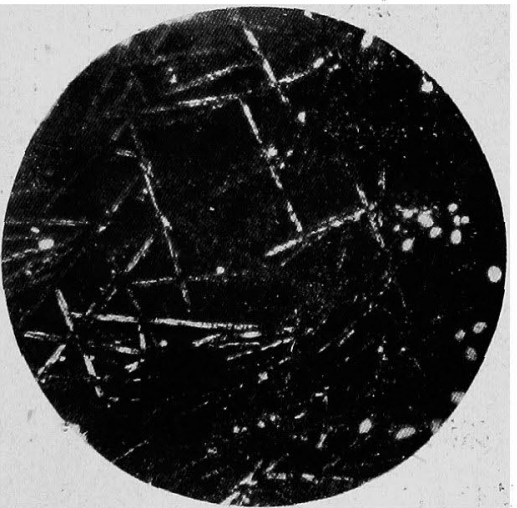

第四圖橔㰖石符體を $1560^{\circ} \mathrm{C}$ 上。 り紱洽せるもの 針狀結品……橔控石 


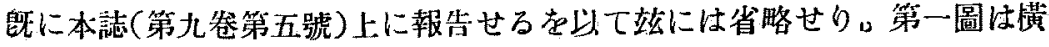
軸に温度,縱軸に粘度の對數をとりたる曲線なり。本圖に見るが如く曲線 孫を以て示せる $I 460^{\circ} \mathrm{C}$ 附近にて急激に傾科を變化す。これ熔體中に急 激に結晶の晶出する䉆めなることは他の例によりて明かなり。

\begin{tabular}{|c|c|c|c|c|c|c|c|c|}
\hline $\begin{array}{l}\text { Lond } \\
\text { grmts } \\
\left(\mathrm{W}^{\prime}\right)\end{array}$ & $\underset{1560^{\circ} \mathrm{C}}{\mathrm{S} a t}$ & $\stackrel{S a t}{1550^{\circ} i}$ & $\begin{array}{c}\mathrm{S} a c \\
1525^{\circ} \mathrm{C}\end{array}$ & $\begin{array}{c}\mathrm{S} a t \\
1500^{\circ} \mathrm{C}\end{array}$ & $\underset{T \pi 75^{\circ}}{S a t}$ & $\begin{array}{c}\mathrm{S} a t \\
1450^{\circ} \mathrm{C}\end{array}$ & $\begin{array}{c}\mathrm{S} a t \\
1425^{\circ} \mathrm{C}\end{array}$ & $\begin{array}{c}\mathrm{S} n t \\
1400^{\circ}\end{array}$ \\
\hline 2.5 & 17.54 & 16.22 & 15.00 & 13.93 & 12.77 & $\ldots . .$. & $\ldots \ldots$ & $\ldots \ldots$ \\
\hline 3 & 24.39 & 23.08 & 21.43 & 20.34 & 20.00 & 12.61 & $\ldots \ldots$ & $\cdots, \ldots$, \\
\hline 4 & 34.88 & 32.97 & 30.93 & 28.57 & $27 \cdot 27$ & 21.28 & $\ldots \ldots$ & ....... \\
\hline 5 & 45.45 & 42.25 & 38.96 & 37.04 & 35.29 & 28.04 & 16.22 & $\ldots \ldots$ \\
\hline 6 & $\ldots \ldots$ & $\ldots \ldots$ & $\ldots .$. & $\ldots \ldots$ & $\ldots \ldots$ & 32.97 & 20.69 & $\ldots \ldots$ \\
\hline 8 & $\cdots \cdots$ & $\ldots \ldots$ & $\ldots \ldots$ & $\ldots \ldots$ & $\ldots \ldots$ & $\ldots \ldots$ & 30.00 & 19.61 \\
\hline 10 & $\ldots \ldots$ & $\ldots .$. & $\ldots \ldots$ & $\ldots$. & ....... & ....... & 37.50 & 26.09 \\
\hline 14 & ....... & ....... & ....... & ...... & $\ldots \ldots$ & ....... & $\ldots \ldots$ & 37.50 \\
\hline 16 & ....... & ....... & ........ & ....... & $\ldots .$. & ....... & $\ldots \ldots$ & 44.78 \\
\hline
\end{tabular}

\begin{tabular}{|c|c|c|c|c|}
\hline $\begin{array}{l}7 \mathrm{emp}^{\circ} \\
\text { in }{ }^{\circ} \mathrm{C} \text {. }\end{array}$ & $k$ & $\mathbf{k}^{\prime}$ & $\begin{array}{c}x_{1}^{\prime} \\
\text { (Poises) }\end{array}$ & $\log \eta^{\prime}$ \\
\hline 1560 & 0.0911 & 0.839 & 98.52 & 1.9935 \\
\hline 1550 & 0.0974 & 0.836 & 107.60 & 2.0318 \\
\hline 1525 & 0.1046 & 0.844 & 118.22 & 2.0727 \\
\hline 1500 & 0.1118 & 0.834 & 129.06 & 2.1108 \\
\hline 1475 & 0.1174 & 0.826 & 137.85 & 2.1394 \\
\hline 1450 & 0.1475 & 0.002 & 186.42 & 2.2705 \\
\hline 1425 & 0.2288 & 1.278 & 333.58 & 2.5232 \\
\hline 1400 & 0.3280 & 1.506 & 537.78 & 2.7306 \\
\hline
\end{tabular}

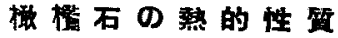

橄㰖石を $1450^{\circ} \mathrm{C}, 1500^{\circ} \mathrm{C}, 1550^{\circ} \mathrm{C}$ 及び $I 560^{\circ} \mathrm{C}$ の四種の温度に30 分間加 熱せるに $1500^{\circ} \mathrm{C}$ のものは加熱せざるものに比し砝んど變化を諗むる能は ざれも゙も $1550^{\circ} \mathrm{C}$ 及び $I 560^{\circ} \mathrm{C}$ に加熱せるものは結晶粒互に融着し僅かに熔 融せる形跡むり之れを檢鏡せるに分解の程度は個々の結晶によりて相哭

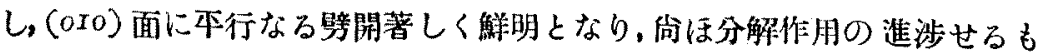


のは分解せる部分が玨紋狀或は海線狀を呈す。第二圖は $1550^{\circ} \mathrm{C} に 30$ 分 間加熱せるもOの $(I 00)$ 面に本行なる結晶斷面の颖微鏡寫真にして濃色の 部分汢分解せるもの，淡色は橄筧石結奛の分解を受けざる部分なり。第三

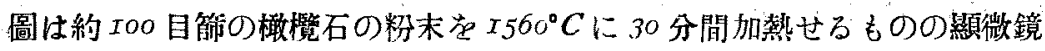
寫鱼にして結晶粒子山牛融融着し僅かに䏚間あるを見るべし。上述の如く 橄攬石は之を $5.560^{\circ} \mathrm{Cに} 30$ 分間加熱するも半融するに過ぎざれども，粘度 测定の場合には此温度附近に長時間加熱せるに螾體となれる范認めたり。

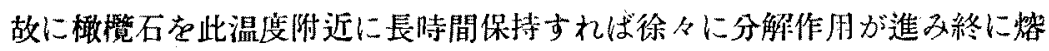
體を生ずるものと考へらる。

第四圖任粘度测定の直前, $1550^{\circ} \mathrm{C}$ に於て白金圆筒中ょり取出したる焪體

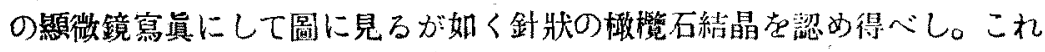
は冷却に際して生ぜるものにして其晶出温度は粘度曲線に矢虎以て示せる $1460^{\circ} \mathrm{C}$ 附近に相當するならん。

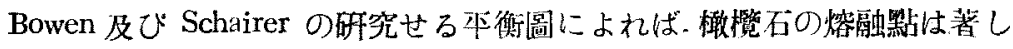
く高きを以て,本實驗の温度籍園にては粘度を测定すること能はざる理な

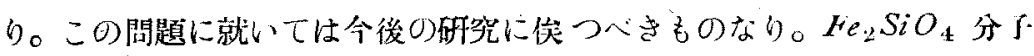

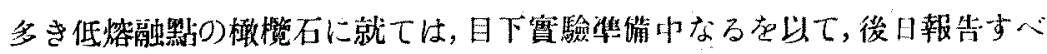
L。

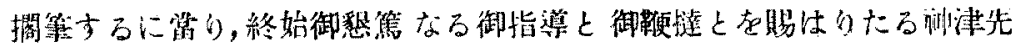
生に整心より感謝す。 